\title{
THEORETICAL APPROACH TO THE PROFILE OF TOURISTS VISITING URBAN TRAVEL DESTINATIONS
}

\author{
LOREDANA MARIA TALPOȘ ${ }^{1}$, CRISTINA BOLOG $^{2}$
}

\begin{abstract}
Theoretical Approach to the Profile of Tourists Visiting Urban Travel Destinations. The tourist profile is a key element in tourism, being addressed both in the academic and professional area. Possessing information regarding the tourist's features leads to market segmentation, creating adequate marketing and management strategies, providing an appropriate tourism offer, choosing the most advantageous promotion channels, obtaining tourists' loyalty or their recommendation to others. Also, urban tourism is a form of tourism practiced by an important number of tourists. Thus, the main purpose of this study is to provide a theoretical approach to the profile of tourists visiting cities and the secondary objectives are to identify research conducted recently on this topic, the approach of this concept by stakeholders and the variables of the profile of these tourists. This research consists of a review of studies and content analysis of the papers written on this topic was realized. Research on the tourist profile has been conducted all over the world, including Romania, approaching the characteristics of tourists with various preferences regarding, for example, the chosen types/forms of tourism, travel services, motivation, satisfaction or loyalty. We identified and analyzed the socio-demographic, geographical and behavioral variables and approached the importance of data regarding tourist features for various stakeholders.
\end{abstract}

Keywords: tourist profile, urban travel destinations, international tourists, content analysis, Romania.

\section{Introduction}

Nowadays, tourism represents: development, economic growth, $10 \%$ of world's GDP, 30\% of services export, 7\% of world's exports, 1/10 of jobs, peace and security, environmental protection or cultural preservation. In the year

\footnotetext{
1 "Babeș-Bolyai" University, Faculty of Geography, Doctoral School of Geography, 5-7 Clinicilor Street, Cluj-Napoca, Romania, e-mail: lore.talpos@gmail.com

2 "Babes-Bolyai" University, Faculty of Geography, 5-7 Clinicilor Street, Cluj-Napoca, Romania, e-mail: cristina.bolog@ubbcluj.ro
} 
2017 there were 1326 million international tourist arrivals, Europe being on the top (51\% from total). Compared to 2016, the international tourist arrivals grew by $7 \%$ in the world and by $8.4 \%$ in Europe (World Tourism Organization, 2018). Also in Romania there was growth in tourist arrivals: 11002522 arrivals (22.54\% being foreigners) in 2016 and 12143346 arrivals (22.72\% foreigners) in 2017 (http://statistici.insse.ro:8077/tempo-online/\#/pages/tables/insse-table). Tourism is characterized by: growing competitiveness, building bridges between people and communities, need for strategies in order to achieve sustainable development, increasing connectivity and mixing the physical and digital world (World Economic Forum, 2017).

Tourism in urban travel destinations is also a popular topic for research. Cities facilitate the access to places where various types or forms of tourism are practiced, such as: urban tourism, cultural tourism, sporting tourism, congress tourism, rural tourism, adventure tourism or ecotourism. Also, in the last 30 years a growing scale of the research on urban tourism topic has been registered, explained by the proliferation of the urban tourism domain sub-themes and the broader development of tourism research (Ashworth \& Page, 2011).

At the end of the 1970's, there appeared a new orientation in Geography, called Behavioral Geography. The responsibility for actions with spatial effect was attributed to the human behavior (Benedek, 1999). "Tourist" and "tourist experience" are fundamental concepts for tourism, being focused starting with the 1960s when the first studies approaching the nature of the experience were realized in a more critical and broader way (Femenia-Serra \& Neuhofer, 2018). Tourists and their behavior or experience are varied (McCabe, 2005; Femenia-Serra et al., 2019), this diversity conducting to studies aiming to define tourist typologies

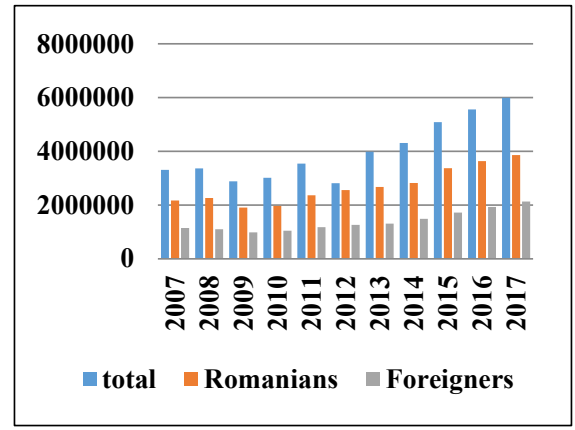

Fig. 1. Number of tourist arrivals in Bucharest and Romanian county seats, except Tulcea

Source: processed after data available on http://statistici.insse.ro:8077/tempoonline/\#/pages/tables/insse-table, 2018 by analyzing aspects such as: socio-economic features, motivations, psychographic aspects, perceptions, decision making or chosen activities (Femenia-Serra et al., 2019).

Urban settlements are origins of most tourists, representing also the travel destination of many persons and an important focal point in numerous tourist itineraries (Ashworth \& Page, 2011). Also, the urban population of the 
world is continuously growing in number and in percentage, having important effects on urban tourism. The economic effect of tourism activity on urban settlements, positive or negative, overlooks the environmental, social or political ones (Ashworth \& Page, 2011). In Romania, urban areas are a popular type of travel destinations.

Also, the tourist profile is a popular topic of interest and research. Searching the key words "tourist profile" on Web of Science, for the completed years, 882 papers have resulted. Analyzing the following graphic, there can be noticed the interest in this aspect.

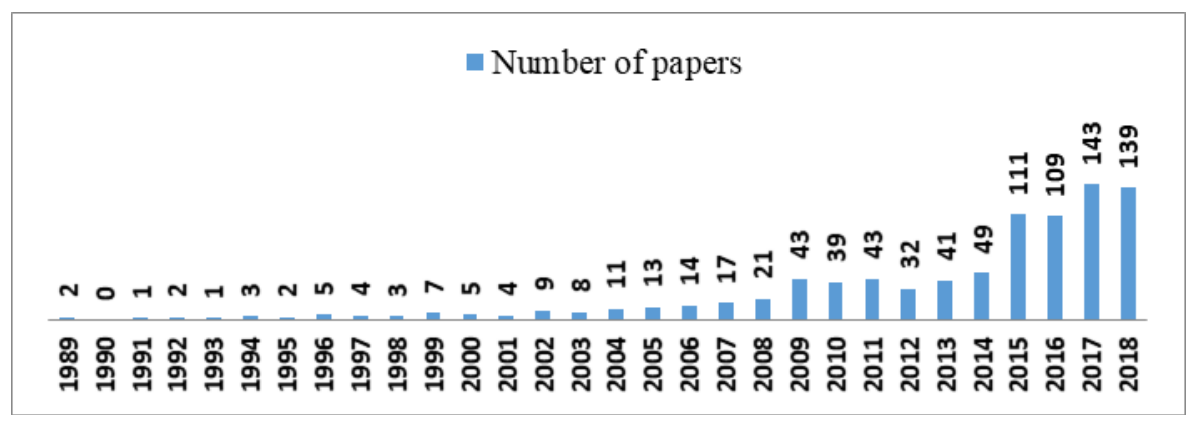

Fig. 2. Number of papers per year

Source: processed according to data from www.webofknowledge.com

Tourist circulation, tourism potential and infrastructure are essential components of the tourism phenomenon (Ciangă, 2007). For the knowledge, understanding and valorization of the tourist circulation, with the ultimate goal of achieving sustainable tourism, the tourist profile has an important role. The tourist profile concept is addressed in both academic and professional area and consists of the tourist's features divided into socio-demographic, geographical and behavioral categories. Academic researchers and different tourism stakeholders should understand the tourists' behavior and know their socio-demographic and geographical features. Also, client knowledge is a strategic fundamental point for the hospitality management, helping to improve the tourism offer, to create customized and adapted services and travel packages, to have good and fruitful relationships with customers and, also, to have suitable and advantageous management and marketing strategies (Adomavicius \& Tuzhilin, 2001; Min et al., 2002; Talón-Ballestero et al., 2018). For the sustainable development of tourism, it is essential that the tourist services and packages be realized according to the need of the tourist demand. 
Tourism market segmentation is done in order to plan and manage the tourist-oriented policies (Brida et al., 2014). Implementation of a marketing strategy in tourism is necessary for a travel destination to acquire a positive image and tailored to the needs, expectations and preferences of its target tourist segments. To meet this goal, it is, firstly, necessary to know the profile of tourists which provides information regarding a range of variables (Costa et al., 2014).

Thus, finding information regarding the tourists' features is at the base of the process needed to be done for sustainable development in tourism. This stage is followed by market segmentation which helps creating adequate tourist packages and tourism development strategies, resulting in sustainable tourism development.

\section{Materials and methods}

Taking into consideration these aspects, the main purpose of this paper is to provide a theoretical approach to the profile of tourists visiting urban travel destinations. Also, the secondary objectives of the paper are:

1) to identify research conducted recently regarding this topic;

2) to identify the importance of the tourist profile for tourism stakeholders;

3) to identify the component parts of the tourist profile.

This research consists of a review of studies approaching the features of tourists. Content analysis of the papers written on this topic was performed. We analyzed articles, conference proceeding and reports. Also, the available database from the internet was analyzed. Information was processed and presented in graphics and tables for a more suitable and easier manner of understanding and analyzing various aspects.

\section{Results and discussions}

The tourist profile is a popular topic for discussion and research, and urban tourism is a form of tourism practiced by an important number of tourists. Thus, there are many written papers approaching various aspects related to the profile and the features of tourists visiting urban travel destinations. Research on this subject was conducted by researchers living in various countries regarding tourists visiting urban travel destinations located in different parts of the world, examples being: Prayag et al., 2013; Central Bureau of Statistics Aruba, 2014; Costa et al., 2014; Stepchenkova et al., 2015; Tsourgiannis et al., 2015; Pinheiro Melo Borges Tiago et al., 2016; Todorovic \& Jovicic, 2016; der Hoed \& Russo, 2017; Gonzales Santa-Cruz \& 
Lopez Guzman, 2017; Observatiori del Turisme a Barcelona Ciutat I Regio, 2017; Jaapar et al., 2017; Talón-Ballestero et al., 2018; Sthapit \& Jimenez-Barreto, 2018, Ramirez et al., 2018. Also in Romania, a country that represents a travel destination which is more popular every year, studies were made about the features of tourists visiting cities, such as: Tudoricu, 2008; Coma et al., 2008, Lazin \& Pop, 2009; Manea et al., 2013, Muntean \& Moisă, 2014; Mahika et al., 2015; Toader et al., 2015; Cosma et al., 2016.

Many studies have been carried out regarding the profile of tourists not relying on the practice of a certain type/form of tourism - e.g. Lazin \& Pop, 2009; Prayag et al., 2013; Central Bureau of Statistics Arruba, 2014; Costa et al., 2014; Muntean \& Moisă, 2014; Tsourgiannis et al., 2015; Pinheiro Melo Borges Tiago et al., 2016; Todorovic \& Jovicic, 2016; Observatori del Turisme a Barcelona Ciutat i Regio, 2017; Talón Ballestero et al., 2018 - or tourists practicing particular types/forms of tourism. The types/forms of tourism approached in the studies analyzed for this paper are: cultural in general - e.g. Cosma et al., 2008; Toader et al., 2015; Gonzales Santa Cruz and Lopez Guzman, 2017; Ramires et al., 2018, event tourism as part of cultural tourism - e.g. Tudoricu, 2008; Mahika et al., 2015; Cosma et al., 2016, visiting friends and relatives - e.g. Stepchenkova et al., 2015, volunteering tourism - e.g. Manea et al., 2013, dental tourism - e.g. Yaapar et al., 2017 and professional tourism - e.g. der Hoed \&Russo, 2017.

Also, studies were conducted approaching tourist profile and different travel services: air transport services - e.g. Costa et al., 2014, traditional accommodation - hotel - e.g. Talón-Ballestero et al., 2018; recently growing in popularity type of accommodation - Airbnb - e.g. Sthapit \& Jimenez Barreto, 2018.

Studies focused on aspects such as the motivation, satisfaction and loyalty: approaching motivation and push and pull factors - e.g. Prayag et al., 2015; Todorovic \& Jovicic, 2016, the variables able to influence satisfaction level and loyalty - e.g. Gonzales Santa-Cruz \& Lopez Guzman, 2017.

Various methods were used in order to obtain information regarding the tourist's profile: surveys were applied - e.g. Stepchenkova et al., 2015, Toader et al., 2015, interviews were conducted - e.g. Sthapit \& Jimenez Barreto, 2018 or information from the database of various stakeholders was used - e.g. Pinheiro Melo Borges Tiago et al., 2016; Talón-Ballestero et al., 2018.

Also, two types of market segmentation may be performed: a priori and a posteriori - e.g. Dolnicar, 2004; Prayag et al., 2013. A priori means obtaining groups of tourists by having a predefined criterion and a posteriori refers at identifying the segments by applying segmentation algorithms (Dolnicar \& Leisch, 2004; Prayag et al., 2013). Example of a study with a priori market segmentation is the one by Stepchenkova et al. (2015) and for a posteriori the one realized by Prayag et al. (2013) or by Pinheiro Melo Borges Tiago et al. (2016). 
Research on tourism and information and communication technologies has focused on tourist experiences and smart travel destinations - e.g. Femenia-Serra \& Neuhofer, 2018, smart tourist profile being a popular topic for research. The "smart" term represents a key concept describing the economic, social and technological development achieved with the use of technology and the widespread adoption of social media (Gretzel et al., 2015) and smart tourism appears from the contact between the tourist experience and ICT (Hunter et al., 2015; Gretzel et al., 2015). Thus, there have been recently conducted studies which have collected, processed and analyzed data from platforms such as TripAdvisor, Booking.com or Facebook - e.g. Ye et al., 2018; Van der Zee \& Bertocchi, 2018.

Different actors contributing to the tourism area have different viewpoints regarding the analysis of the tourist profile. Thus, it is important to analyze the approaches of elements such as institutions, travel agencies or accommodation units regarding this topic.

Tourists' features are a topic of interest for organizations that are studying and regularly publishing reports to present the current state and trends in tourism. For example, the World Economic Forum has published information on age-groups features of a particular interest: "millennials" and "baby-boomers" (World Economic Forum, 2017). Also, research has been carried out by various institutions at national or regional level (Central Bureau of Statistics Aruba, 2014; Observatori del Turisme a Barcelona Ciutat i Regio, 2017) analyzing variables related to the geographical, socio-demographic and behavioral features.

In Romania, until recently there existed a Ministry of Tourism (now part of the Ministry of Economy, Energy and Business Environment), part of the Government, national authority and structure of the central public administration which had the mission to create the tourism strategies, to observe and give direction in the Romanian tourism. Also, recently, the Incoming Romania Association has been created with the purpose of identifying and solving the problems encountered by incoming tourists in Romania.

Also, in 2007, when Romania has joined the European Union, a masterplan for the development of national tourism in the period 2007-2026 was conceived in collaboration with the World Tourism Organization. Then, one noticed the low amount of information or lack of information about a series of variables necessary for identifying tourists' profile (Master Planul pentru Dezvoltarea Turismului Național 2007-2026, partea 1).

Knowing the profile of tourists is essential for national, regional and local authorities in conceiving development strategies in general and those of tourism development in particular. After discovering the traits of the 
tourists, the segmentation of the tourist market takes place, the information on the traits of the tourists in each segment providing material for the elaboration of the strategic material by establishing the strategic directions.

Also, at the level of urban destinations, it is necessary to adopt development strategies with a section dedicated to the tourism development strategy. An example of a written strategic document is the one regarding ClujNapoca City, where the features of tourism demand have been taken into account (Strategia de dezvoltare a municipiului Cluj-Napoca, 2014-2020).

Smart destinations need to provide adequate and smart tourist information and services and they have to be aware of the context of the tourist. This context is described by two areas: the personal and travel traits of tourists, on one hand, and the environment in which they travel - location, social aspects, etc., on the other hand (Lamsfus et al., 2015; Femenia-Serra \& Neuhofer, 2018).

Destination Management Organizations are interested in creating a profile of the tourist. To find out the tourists' features, nowadays large amount of data is available in the virtual area ("big-data" or "open-data"), thanks to the insertion of information by tourists. Thus, studies have recently collected, processed and analyzed data from platforms such as: TripAdvisor, Booking.com or Facebook (e.g. Ye et al., 2018; Van der Zee \& Bertocchi, 2018).

Tourist Information Centers have the tasks to promote travel destinations and attractions and to provide information about and reservation for various services (Bahre et al., 2009). In order to fulfill the tasks efficiently and effectively, it is needed to know who the tourists visiting the destination are and what are their features and interests. So, research is made on this topic, an example being the one realized by Lazin and Pop (2009).

The tourist profile provides useful information for travel agencies. Travel packages should be created based on understanding, for example, the tourist's motivation to achieve the satisfaction of that traveler (Gnoth, 1997; Wong et al., 2017), growing the chances of turning the tourist into a loyal customer that will buy tourism products again.

Accommodation units can be divided into traditional ones - used for a long time (hotels, guesthouses), and ones that started to be popular more recently (Airbnb, Couch-Surfing) or staying at friends or relatives. Features of tourists staying in accommodation units in cities have been studied (TalónBallestero et al., 2018; Sthapit \&Jimenez Barreto, 2018). Some accommodation units, mainly hotels, gathered and recorded information in the Customer Relationship Management Systems (Sarmaniotis et al., 2013; Talón-Ballestero et al., 2018) as a strategy to improve both customer level of satisfaction and his or her retention (Padilla-Melendez \& Garrido-Moreno, 2013; Talón-Ballestero et al., 2018). 
In order to identify the profiles of tourists from urban areas, information regarding different variables was searched. In the following lines, we approached the categories of variables used in order to identify and characterize the profile of the tourists.

After analyzing studies approaching tourists' features, information resulted regarding their socio-demographic and geographic features. This information is presented in the following table.

Table 1. Socio-demographic and geographical features

\begin{tabular}{|c|c|c|}
\hline \multicolumn{3}{|c|}{ GENERAL } \\
\hline Age & Gender & \\
\hline Civil status & $\begin{array}{c}\text { Number of persons from the } \\
\text { household }\end{array}$ & $\begin{array}{c}\text { Existance of children } \\
\text { in the household }\end{array}$ \\
\hline & Occupational status & Occupation \\
\hline Education & Financial well-being & \\
\hline INCOME & GEOGRAPHICAL/PROVENANCE \\
\hline Income & Nationality & Spoken language/s \\
\hline Country of residence \\
\hline $\begin{array}{c}\text { Domestic/international } \\
\text { tourists }\end{array}$ & $\begin{array}{c}\text { Type of residence } \\
\text { environment (urban/rural) }\end{array}$ & \\
\hline
\end{tabular}

Source: processed after: Tudoricu, 2008; Cosma et al., 2008; Lazin \& Pop, 2009; Manea et al., 2013; Prayag et al. 2013; Central Bureau of Statistics, Aruba, 2014; Costa et al., 2014; Muntean \& Moisă, 2014; Stepchenkova et al., 2015; Tsourgiannis et al., 2015; Mahika et al., 2015; Todorovic \& Jovicic, 2016; Cosma et al., 2016; Pinheiro Malo Borges Tiago et al., 2016; der Hoed \& Russo, 2017; Gonzales Santa-Cruz \& Lopez Guzman, 2017; Observatori del Turisme a Barcelona Ciutat i Regio, 2017; Jaapar et al., 2017; Talón Ballestero et al., 2018; Sthapit \& Jimenez Barreto, 2018; Ramires et al., 2018.

Thus, the socio-demographic and geographical features can be grouped into the following categories of variables: general, related to the household, education and occupation, income and geographical/provenance.

International travelers are categorized not according to their citizenship, but to their country of residence (Luxembourg: Publications Office of the European Union, 2018) which is the country from the identity card or it can also be the state where a person is staying for more than a year and represents his/her economic interest spending there the biggest amount of time (UNWTO, 2015). 
Analyzing studies approaching tourists' behavioral characteristics, the information presented in the following table resulted. These features can be divided according to the three stages of the tourist experience: before, during and after travel (Stepchenkova, 2015). One may consider that the features before travel refer to the motivation and travel planning, those during travel - to the services used (for transportation, accommodation, eating, activities) and those after travel - to the evaluation (including the satisfaction, good and weak aspects of the destination and experience, intention to revisit and willingness to recommend).

Table 2. Behavioral characteristics

\begin{tabular}{|c|c|c|}
\hline \multicolumn{3}{|c|}{ MOTIVATION } \\
\hline $\begin{array}{l}\text { Main purpose of the } \\
\text { visit/travel }\end{array}$ & Push factors & Pull factors \\
\hline \multicolumn{3}{|c|}{ Frequency of practicing a certain type/form of tourism } \\
\hline \multicolumn{3}{|c|}{ TRAVEL PLANNING } \\
\hline Type of travel arrangement & $\begin{array}{l}\text { Reservation period of time } \\
\text { in advance }\end{array}$ & Length of stay \\
\hline Preferred destination & Primary destination & Type/s of destination/s \\
\hline Destination/s visited & Existence of prior visits & Number of prior visits \\
\hline Source/s of information & Travel concerns & Spendings \\
\hline Type of travel partners & Number of travel partners & Month/s when travel \\
\hline \multicolumn{3}{|c|}{ SERVICES USED } \\
\hline $\begin{array}{c}\text { Type of transportation used to } \\
\text { the destination }\end{array}$ & Type of flight/airline & $\begin{array}{l}\text { Means of transportation } \\
\text { within the destination }\end{array}$ \\
\hline Type of accommodation & $\begin{array}{l}\text { Level of comfort of the } \\
\text { accommodation unit }\end{array}$ & $\begin{array}{c}\text { Uses of time share } \\
\text { properties }\end{array}$ \\
\hline $\begin{array}{c}\text { Preferred types of eating } \\
\text { places }\end{array}$ & $\begin{array}{c}\text { Types of activities } \\
\text { performed }\end{array}$ & Tourist sights visited \\
\hline Travel within wider area & & \\
\hline \multicolumn{3}{|c|}{ EVALUATION } \\
\hline Satisfaction & $\begin{array}{c}\text { Words associated with a } \\
\text { destination }\end{array}$ & $\begin{array}{l}\text { Top destinations } \\
\text { attractions }\end{array}$ \\
\hline Reasons for not coming & Complaints & \\
\hline Intention to revisit & $\begin{array}{l}\text { Willingness to practice } \\
\text { again a certain form of } \\
\text { tourism }\end{array}$ & $\begin{array}{l}\text { Willingness to } \\
\text { recommend }\end{array}$ \\
\hline
\end{tabular}

Source: processed after: Tudoricu, 2008; Cosma et al., 2008; Lazin \& Pop, 2009; Manea et al., 2013; Prayag et al. 2013; Central Bureau of Statistics, Aruba, 2014; Costa et al., 2014; Muntean \& Moisă, 2014; Stepchenkova et al., 2015; Tsourgiannis et al., 2015; Mahika et al., 2015; Toader et al. 2015; Todorovic\&Jovicic, 2016; Cosma et al., 2016; Pinheiro Malo Borges Tiago et al., 2016; der Hoed \& Russo, 2017; Gonzales Santa-Cruz \& Lopez Guzman, 2017; Observatori del Turisme a Barcelona Ciutat i Regio, 2017; Jaapar et al., 2017; Talón Ballestero et al., 2018; Sthapit \& Jimenez Barreto, 2018; Ramires et al., 2018 
Motivation is an important aspect of the tourists' profile, starting and orienting the traveler's behavior. People can visit cities for a broad range of motivations, urban travel destinations being characterized by both diversity and density of facilities, functions, built forms, people and culture. The diversity of activities and motives and their density is a feature of cities' urban character (Ashworth \& Page, 2011).

For travel planning, there are a variety of useful variables to be taken into consideration when trying to describe the profile of tourist. These variables may be related to types of travel arrangement, reservation, travel destination, length of stay, repetitiveness of the visit, sources of information, travel concerns, spending, travel partners or period of traveling.

The main purpose of the travel variable is used in numerous studies and it represents the purpose that determines the realization of the travel. In its absence, travel does not take place (UNWTO - Understanding Tourism Basic Glossary). For the main purpose of the travel, UNWTO uses three categories: holiday, leisure and recreation; personal purpose (visiting friends and relatives, religion, health, other) and business and professional (UNWTO, 2018).

Various models of analyzing tourists' motivations have been used over time, such as: Maslow's hierarchy of needs, Plog's allocentric and psychocentric model, the theories about expectancy and value, travel career ladder, motivation and expectation emergence or the push-pull model, in the present, the last one being considered the most popular model (Dann, 1977; Prayag \& Hosany, 2014; Prayag et al., 2015). The push factors represent reasons that determine people decide to make a travel, while pull factors (destination attributes) are motives that make a tourist choose a certain travel destination, as a result of the push factors (Dann, 1977; Prayag et al., 2015). Push factors are internal or sentimental and pull factors are external or cognitive (Yfantidou et al., 2011).

Regarding spending, tourists visiting urban destinations spend more per person than, for example, the seaside ones, also as a consequence of their bigger dependence on catered accommodation, but there is a disadvantage regarding the fact that they are more difficult to attract, to grow their length of stay in the city and, afterwards, to determine to revisit the destination (Ashworth \& Page, 2011).

During their travel, tourists use various services. The basic travel services are the ones related to transportation, accommodation and eating (Nicoară, 2010). Also, it is useful the information regarding other services used by tourists visiting cities such as the ones about: business, recreation and entertainment or personal purposes.

Tourists can choose a certain service (e.g. accommodation) based on variables such as: location, quality, price, rating made by others (Verma, 2010; Serra Cantallops \& Salvi, 2014). Word of mouth (WOM) represents one of the 
favorite sources of information for tourists that decided to make a travel, representing a communication of a person after receiving a good, service, experience. Nowadays the electronic word of mouth (eWOM), consisting in aspects such as online reviews or suggestions, is growing in popularity (Serra Cantallops \& Salvi, 2014).

Satisfaction represents the extent to which the evaluation of a tourist regarding the features of a travel destination exceed the expectations he/she had about those features (Tribe \& Snaith, 1998; Wong et al. 2017) and can lead to revisiting a place or to the willingness to recommend it as a travel destination. One may analyze the overall satisfaction at the destination or satisfaction related to various components such as: natural or anthropogenic attractions, accessibility and mobility, tourist services, tourism signposting and information, internet quality, hospitality, entertainment, cleanliness, value for money (Central Bureau of Statistics Aruba, 2014; Observatori del Turisme a Barcelona Ciutat i Regio, 2017; Ramires et al., 2018).

Tourists visiting cities have, also, the following behavioral characteristics: rapidity - consuming services and tourist products rapidly, selectivity - the person using just a small part of the city offer, capriciousness - vulnerable to changes in fashion, lifestyles or tastes, and infrequency - less likely to revisit the travel destination than persons that travel in other types of destinations (Ashworth \& Page, 2011).

Modifications in tourists' behavior have occurred due to the development of information and communication technology (Serra Cantallops \& Salvi, 2014).

A popular type of tourists, the smart tourist, is open to sharing with tourism stakeholders information like: basic personal information, location, information from social media profiles, his/her preferences. The person is aware that the sharing of this information is beneficial for receiving information and customized travel services and experiences (Femenia-Serra et al., 2019).

\section{Conclusion}

In conclusion, understanding the "tourist profile" concept and its importance are essential for both academic researchers and tourism stakeholders. The main result of this paper is the deepening of the understanding regarding tourists' profile in general and of the people visiting urban travel destinations in particular. We identified research conducted in the last years approaching this topic and content analysis was performed. The importance of the tourist profile for various tourism stakeholders was mentioned and, also, the component parts of the tourist profile were identified and presented. 
It resulted that the tourist profile is a topic of research which is growing in popularity, studies on this subject being conducted in various countries, among them also Romania. Studies regarding tourists practicing particular types/forms of tourism and studies not relying on practicing a certain type were both conducted. Studies approached features of tourists using various travel services and also focused on motivation, satisfaction or loyalty in terms of tourist profile.

It turned out that various methods can be applied in order to collect data about tourists' features, for example: surveys using questionnaires, interviews or using database from various tourism actors. Market segmentation may be performed in two ways: a priori and a posteriori.

There are various stakeholders in the field of tourism, such as: national, regional or local authorities or private associations, destination management organizations, tourist information centers, travel agencies or accommodation units.

The tourist profile is important for all stakeholders mentioned above and it consists of socio-demographic, geographical and behavioral characteristics. The socio-demographic features are related to aspects such as age or gender, household, education, occupation or income; the geographical ones refer to country/county of residence, domestic/international tourists, urban/rural type of residence, environment, nationality or spoken language/s, while the behavioral characteristics consists of variables regarding motivation, travel planning, services used or evaluation.

In the end, it resulted that the tourist profile is important for every stakeholder and the field of tourism as a whole. Finding information regarding variables that form the tourist's profile is necessary to elaborate suitable tourism strategies. This step is followed by market segmentation, which helps creating adequate tourist packages and tourism development strategies, resulting in sustainable tourism development. Thus, knowledge regarding the profile of the tourist is a fundamental element for both research and practice.

\section{REFERENCES}

1. Adomavicius, G., Tuzhilin, A. (2001), Using data mining methods to build customer profiles. Computer, vol. 34(3), p.74-82, doi.org/10.1109/2.901170.

2. Ashworth, G., Page, S.J. (2011), Urban Tourism Research: Recent Progress and current paradoxes, Tourism Management, vol. 32, p. 1-15.

3. Bahre, Heike; Casovschi, Carmen; Năstase, Carmen (2009), The Profile of the Tourism Information Center Offices in Romania, Amfiteatru Economic, vol. XI, no. 25 , p. 51-60. 
4. Benedek, J. (1999), Organizarea spațiului rural: studiu de caz Dealurile Bistriței, Teză de doctorat, Univ. "Babeș-Bolyai”, Cluj-Napoca.

5. Brida, J.G., Disegna, M., Scuderi, R. (2014), Segmenting visitors of cultural events: The case of Christmas Market, Expert Systems with Applications, vol. 41, p. 45424553.

6. Ciangă, N. (2007), România: geografia turismului, Ediția a II-a, Edit. Presa Universitară Clujeană, Cluj-Napoca.

7. Cosma, Smaranda Adina; Negrușă, Adina Letiția (2008), The Place of Cultural Tourism for Cluj-Napoca Romania, as a Tourist Destination, WSEAS International Conference on Cultural Heritage and Tourism, vol. 5, issue 7, p. 403-413, Heraklion, WSEAS Transactions on Business and Economics.

8. Cosma, Smaranda Adina; Bota, M., Fleșeriu, Cristina; Negrușă, Adina Letiția; Toader, V., Rus, Rozalia Veronica, (2016), Some Considerations Regarding Motivations and Overall Perceptions on Film Festivals, Amfiteatru Economic, vol. 18, special issue 10, p. 929-943.

9. Costa, J., Moreira, M., Vieira, F. (2014), Profile of the tourists visiting Porto and the North of Portugal, Worldwide Hospitality and Tourism Themes, vol. 6, issue 5, p. 413-428, DOI: 10.1108/WHATT-09-2014-0027.

10. Dann, G.M.S. (1977), Anomie, Ego-Enhancement and Tourism, Annals of Tourism Research, vol. 4 (4), p.184-194.

11. den Hoed, W, Russo, A.P. (2017), Professional travellers and tourist practices, Annals of Tourism Research, vol 63, p. 60-72.

12. Dolnicar, S. (2004), Beyond "Comonsense Segmentation": A Systematics of Segmentation Approaches in Tourism, Journal of Travel Research, vol. 42 (3), p. 244-250, doi:10.1177/0047287503258830.

13. Dolnicar, S., Lesch, F. (2004), Segmenting Markets by Bagged Clustering, Australasian Marketing Journal, Vol. 12 (1), p. 51-65, doi: 10.1016/S1441-3582(04)70088-9.

14. Femenia-Serra, F., Neuhofer, B. (2018), Smart tourism experiences: conceptualisation, key dimensions and research agenda, Investigaciones Regionales - Journal of Regional Research, vol.42, p. 129-150.

15. Femenia-Serra, F., Neuhofer, B., Ivars-Baidal, J. A. (2019). Towards a conceptualisation of smart tourists and their role within the smart destination scenario, The Service Industries Journal, vol. 39 (2), p. 109-133, doi:10.1080/02642069.2018.1508458.

16. Gonzales Santa-Cruz, F., Lopez-Guzman, T. (2017), Culture, Tourism and World Heritage Sites, Tourism Management Perspectives, vol. 24, p. 111-116, doi: 10.1016/j.tmp.2017.08.004.

17. Gnoth, J. (1997), Tourism Motivation and Expectation Formation, Annals of Tourism Research, vol. 24 (2), p. 283-304.

18. Gretzel, U., Sigala, M., Xiang, Z., Koo, C. (2015), Smart Tourism: Foundations and Developments, Electronic Markets, doi: 10.1007/s12525-015-0196-8.

19. Hunter, W. C., Chung, N., Gretzel, U., \& Koo, C. (2015), Constructivist research in smart tourism, Asia Pacific Journal of Information Systems, 25 (1), p. 105-120. 
20. Jaapar, M., Musa, Ghazali, Moghavvemi, S., Saub, R. (2017), Dental Tourism: Examining Tourist Profiles, Motivation and Satisfaction, Tourism Management, vol. 61, p. 538-552.

21. Lamsfus, C., Wang, D., Alzua-Sorzabal, A., and Xiang, Z. (2015), Going mobile: Defining context for on-the-go travelers, Journal of Travel Research, 54 (6), p. 691-701.

22. Lazin, M.C., Pop, M.D. (2009), The Profile of Foreign Tourists Who Visit Cluj-Napoca, International Conference "Marketing - from information to decision". $2^{\text {nd }}$ edition.

23. Mahika, Elena Cristina, Rădulescu, R., Aluculesei, Alina Cerasel (2015), The Behaviour of Romanian Tourists Regarding the Attendance at Festivals, Procedia Economics and Finance, vol. 23, p. 1239 - 1244.

24. Manea, Gabriela, Nae, Mariana, Matei, Elena, Vijulie, Iuliana, Târlă Laura (2013), Raising Awareness of Volunteer Tourism: Experiencing the Volunteer Tourism Among Students and Young Researchers, GeoJournal of Tourism and Geosites, year 2, no. 2, vol. 12, p. 120-128.

25. McCabe, S. (2005), Who is a tourist?, Tourist Studies, vol. 5 (1), p. 85-106 doi: $10.1177 / 1468797605062716$.

26. Min, H., Min, H., \& Emam, A. (2002), A data mining approach to developing the profiles of hotel customers, International Journal of Contemporary Hospitality Management, 14 (6), p. 274-285. http://dx.doi.org/10.1108/09596110210436814.

27. Muntean, Andreea \& Moisă, Claudia (2014), The Profile of the Tourists Who Choose Alba County as a Tourist Destination, Annales Universitatis Apulensis Series Oeconomica, vol. 16, issue 2, p. 229-243.

28. Nicoară, L. (2010), Organizarea serviciilor în turism, Cluj-Napoca.

29. Padilla-Meléndez, A. \& Garrido-Moreno, A. (2013), Customer relationship management in hotels: Examining critical success factors, Current Issues in Tourism, 17 (5), p. 387-396, http://dx.doi.org/10.1080/13683500.2013.805734.

30. Pinheiro Melo Borges Tiago, Maria Teresa, De Almeida, J.P., Gomes Borges Tiago F., Costa Dias Faria, Sandra Micaela (2016), Baby Boomers turning grey: European profiles, Tourism Management, vol. 54, p. 13-22.

31. Prayag, G., Hosany, S. (2014), When Middle East Meets: Understanding the Motives and Perceptions of Young Tourists from United Arab Emirates, Tourism Management, vol. 40, p. 35-45.

32. Prayag, G., Disegna, Marta, Cohen S.A., Yang (Gordon) H. (2015), Segmenting Markets by Bagged Clustering: Young Chinese Travelers to Western Europe, Journal of Travel Research, vol. 54 (2), p. $234-250$.

33. Ramires, A., Brandao, F., Sousa, A.C. (2018), Motivation-Based Cluster Analysis of International Tourists Visiting a World Heritage City: The Case of Porto, Portugal, Journal of Destination Marketing and Management, vol. 8., p. 49-60, DOI: 10.1016/j.jdmm.2016.12.001.

34. Sarmaniotis, C., Assimakopoulos, C., \& Papaioannou, E. (2013), Successful implementation of CRM in luxury hotels: Determinants and measurements, EuroMed Journal of Business, 8 (2), p. 134-153, http://dx.doi.org/10.1108/ emjb-06-2013-0031. 
35. Serra-Cantallops, A., Salvi, F. (2014), New consumer behavior: A review of research on eWOM and hotels, International Journal of Hospitality Management, vol. 36, p. 41-51.

36. Stepchenkova, S., Shichkova, E., Kim, H., Pennington-Gray, L., Rykhtik, M. (2015), Segmenting the 'visiting friends and relatives' travel market to a large urban destination: The Case of Nizhni Novgorod, Russia, Journal of Destination Marketing \& Management, vol. 4, issue 4, p. 235-247, doi: 10.1016/j.jdmm.2015.09.001.

37. Sthapit, E., Jimenez-Barreto, J. (2018), Exploring Tourists' Memorable Hospitality Experiences: an Airbnb Perspective, Tourism Management Perspectives, vol. 28.

38. Talón-Ballestero, Pilar; Gonzales-Serrano, Lydia; Soguero-Ruiz, Cristina; MunozRomero, S.; Rojo-Alvarez, J.L. (2018), Using Big Data from Customer Relationship Management Information Systems to Determine the Client Profile in the Hotel Sector, Tourism Management, vol. 68, p. 187-197, https://doi.org/10.1016/ j.tourman.2018.03.017.

39. Tribe, J. \& Snaith, T. (1998), From SERVQUAL to HOLSAT: Holiday Satisfaction in Varadero, Cuba, Tourism Management, vol. 19 (1), p.25-34.

40. Toader, V., Negrusa, Adina Letiția, Cosma, Smaranda, Bolog, Cristina (2015), Cultural tourist's behavior - Case study foreign tourists in Cluj-Napoca, Proceedings of the International Conference SCience in TEchnology - ScinTE-2015, p. 34-37.

41. Todorovic, N., Jovicic, D. (2016), Motivational Factors of Youth Tourists Visiting Belgrade, J. Geogr. Inst. Cvijic, vol. 66, issue 2, p. 273-289, DOI:10.2298/IJGI1602273T.

42. Tsourgiannis, L., Delias, P., Polychronidou, P., Karasavvoglou, A., Valsamidis, S. (2015), Profiling Tourists Who Have Holidays in the Region of Eastern Macedonia and Thrace in Greece, Procedia Economics and Finance, vol. 33, p. 450-460.

43. Tudoricu, Anca (2008), Event Tourism in Romania - A Tourist Profile, Human Geographies Journal of Studies and Research in Human Geography, vol. 2, p. 95-100.

44. Van der Zee, E., Bertocchi, D. (2018). Finding Patterns in Urban Tourist Behaviour: a Social Network Analysis Approach Based on TripAdvisor Reviews, Information Technology \& Tourism, vol. 20, p. 153-180, doi.org/10.1007/s40558-018-0128-5.

45. Verma, R. (2010), Customer Choice Modeling in Hospitality Services: A Review of Past Research and Discussion of Some New Applications, Cornell Hospitality Quarterly, vol. 51 (4), p. 470 -478, doi: 10.1177/1938965510378829.

46. Wong, B.K.M., Musa, G., Taha, A.Z. (2017), Malaysia my Second Home: The influence of Push and Pull Motivations on Satisfaction, Tourism Management, vol. 61, p. 394-410, https://doi.org/10.1016/j.tourman.2017.03.003.

47. Ye, B.H., Luo, J.M., Vu, H.Q. (2018), Spatial and Temporal Analysis of Accommodation Preference Based on Online Reviews, Journal of Destination Marketing \& Management, vol. 9, p.288-299.

48. Yfantidou, G., Costa, G., Michalopoulou, M. (2011), Human needs determining the profiles of popular tourist roles in Greece, Studies in Physical Culture and Tourism, vol 18, no. 1, p.59-70.

49. Central Bureau of Statistics Aruba (2014), Tourism, Central Bureau of Statistics, Oranjestad. 
50. Luxembourg: Publications Office of the European Union, (2018), The EU in The World 2018 Edition, Imprimerie Centrale in Luxembourg, DOI: 10.2785/990579.

51. Master Planul pentru Dezvoltarea Turismului Național 2007-2026, part 1 http://turism.gov.ro/web/wp-content/uploads/2017/05/masterplan_partea1.pdf, accesed on 10.11.2018.

52. Observatori del Turisme a Barcelona ciutat i regio (2017), 2017 Barcelona Tourism Activity Report, https://ajuntament.barcelona.cat/turisme/en/estadistiques_enquestes, accessed on 27.04.2019.

53. Strategia de dezvoltare a municipiului Cluj-Napoca, 2014-2020 - http://cmpg.ro/ wp-content/uploads/2015/05/strategie-cluj-napoca-2014-2020.pdf accessed on 14.11.2018.

54. World Economic Forum (2017), The Travel\&Tourism Competitiveness Report 2017.

55. United Nations World Tourism Organization (2018), UNWTO Tourism Highlights, 2018 Edition, UNWTO, Madrid, DOI: https://doi.org/10.18111/9789284419876, https://www.e-unwto.org/doi/pdf/10.18111/9789284419876, accessed on 08.10 .2018 .

56. UNWTO - Understanding Tourism Basic Glossary, http://cf.cdn.unwto.org/sites/ all/files/docpdf/glossaryenrev.pdf, accessed on 08.10.2018.

57. http://statistici.insse.ro:8077/tempo-online/\#/pages/tables/insse-table, accessed 20 December 2018. 